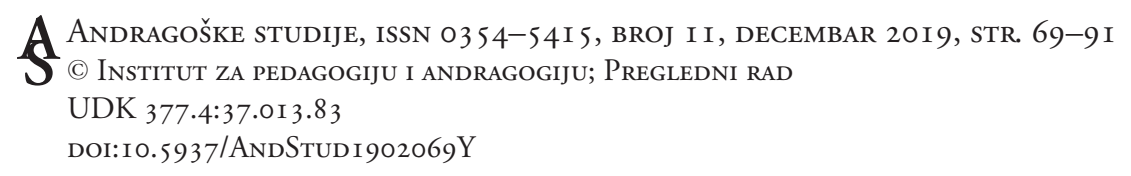

Deisi C. Yunga ${ }^{1}$

Eötvös Loránd University, Hungary

\title{
Transformative Learning: The Richness of Formality and Informality ${ }^{2}$
}

\begin{abstract}
In the past, the idea of 'learning after the completion of formal education' was not an essential element of professional growth. Currently, non-formal and informal learning, as part of lifelong knowledge acquisition and development, are acknowledged as crucial for the constant progress of professionals to deal with the ever-growing challenges of the world of work. This paper uses an exploratory design methodology to elaborate on how lifelong learning as a methodology and strategy for professional development can be achieved through formal and informal learning on the basis of and guided by the transformative learning theory. By examining the historical context, themes, components, and critical review of Mezirow's transformative learning theory, the relevance, effectiveness and applicability of transformative learning methodology is deduced for the teaching profession.
\end{abstract}

Keywords: transformative learning, formal learning, informal learning, lifelong learning, transformative learning theory.

\section{Introduction}

In the past, the concepts of 'lifelong learning' and 'acquisition of learning after formal education' were not considered highly relevant elements of professional growth (Yang \& Valdés-Cotera, 2011). From this perspective, all learning that occurred in the working context was merely a side benefit of being employed and not an integral part of the working environment, since most learning situations were unplanned and uncontrolled. However, with changes such as globalization, technology, and a shift towards a knowledge-based workforce, there is a need for complementary and supplementary learning methods for profes-

\footnotetext{
${ }^{1}$ Deisi C. Yunga, EDiTE Programme, Adult Education Institute, Eötvös Loránd University, Budapest-Hungary (deisi.yunga@gmail.com).

2 This paper is part of a project that has received funding from the European Union's Horizon 2020 research and innovation program under the Marie-Sklodowska-Curie grant agreement number 676452.
} 
sional development aimed at achieving and maintaining employees' competences (Du Plessis, 2009).

Organizations and current job markets are demanding more abilities, skills, knowledge and experiences to meet the ever-increasing and evolving workplace roles (Du Plessis, 2009). Because of the very specific demands of today's labor market, professionals are lining towards constant intellectual development and the cultivation of lifelong learning since the workplace is one of the most important settings where professional learning occurs (Cheetham \& Chivers, 2001; Eraut, 2004). These dynamisms have intensified the need for learning beyond curriculum-based and structured education systems in an effort to keep up to date with current competencies required for career sustenance and growth.

As a result of the realization of the importance of ongoing professional development, much focus has been shifted to learning outside classrooms through lifelong learning. Various studies have provided significant insight into how learning takes place in the workplace through day-to-day work in the form of participation in communities of practice, informal conversations, etc. (Cheetham \& Chivers, 2001; Eraut, 2004), which contain the elements and perspective of lifelong learning.

The study discusses the elements and concepts of the transformative learning theory and analyses how it could help further the effectiveness and efficiency of formal and informal learning in expanding one's knowledge base, skills and experiences, described as transformative professional learning. By doing so, the paper provides insight into future efforts where learners can better assimilate and hone methods on 'how to learn' alongside knowledge crucial to their fields and interests, in an effort to provide learning tools which may translate across shifts in professional paths or socio-cultural environments. These are the phenomena that are quite common today, both in the educational sector as well as in the labor market sector.

\section{Lifelong Learning}

The US Department of Education and Science (2000) defines lifelong learning as the continuous and voluntary pursuit of knowledge, building of skills, and improvement of abilities for personal or professional reasons. Lifelong learning is further explained by Laal (2011) as "a process of becoming aware of the frame of reference within which we think, feel, and act, becoming critical of its adequacy with conscious of where it comes, developing newer more adequate frames of reference which are more inclusive, and discriminating of experience ... and fi- 
nally acting out of this frame of reference" (p. 471). Lifelong learning enhances social inclusion, active citizenship, personal development, self-sustainability, as well as competitiveness and employability (Communication from the Commission, 2006).

\section{Formal and Informal Learning}

In the last century, massive socio-political shifts have completely changed the way learning acquisition has been perceived. Preeminently, the $20^{\text {th }}$ and $21^{\text {st }}$ centuries witnessed an unprecedented change in international policy, commerce, and socio-cultural dynamics. The process of learning acquisition was mainly linked to formal educational institutions while other types of learning were considered secondary concerns (Collins \& Halverson, 2010). However, scholars began to support the idea of informal learning and acknowledged that much of successful learning takes place outside formal education institutions (Scribner \& Cole, 1973).

Moreover, it was accepted that the terms of formality and informality were attributes present in all learning situations and even in the workplace context (Colley, Hodkinson \& Malcolm, 2003). In fact, Billet (2002) argued that formal and informal learning are not distinct from one another. Even informal practices and activities through which learning takes place are at least partially formalized. Nevertheless, this paper adopts the definitions of the CEDEFOP glossary to define formal and informal learning in the following fashion:

Formal learning consists of learning that occurs within an organized and structured context (formal education, in-company training), and that is designed as learning. It may lead to formal recognition ( $\mathrm{di}$ ploma, certificate) (Tissot, 2004).

Informal learning is the learning resulting from daily activities related to work, family, or leisure. It is often referred to as experiential learning and can, to a certain degree, be understood as accidental learning. It is not structured in terms of learning objectives, learning time, and/or learning support. Typically, it does not lead to certification. Informal learning may be intentional but, in most cases, it is nonintentional (or 'incidental'/random) (Tissot, 2004).

Beyond these definitions, the differentiation of these concepts goes further than mere classification. For instance, formal learning is an intentionally planned learning activity while informal learning is seen as non-intentional with no plan- 
ning (Laal, 2011). Formal learning leads to high-status knowledge and is associated with education in schools and universities (Bernstein, 1971). Historically, formal learning has been perceived as more advantageous through the formal acquisition and recognition of a diploma while non-institutional learning has been overlooked or dismissed.

However, the changing nature of jobs has led to informal learning being praised for its flexibility of content and structure that makes learning fun, spontaneous, and fulfilling for employees (Billet, 2004). Both informal and formal forms can lead to transformative learning if conducted under the appropriate theoretical framework such as the transformative learning theories for adult learning (Malcolm, Hodkinson \& Colley, 2003; Santalucia \& Johnson, 2010).

Finally, the definitive boundaries of lifelong learning are broad but in terms of structure and intention, lifelong learning is characterized by formal, informal and non-formal learning forms and the learner is considered to be at the core of learning (Laal, 2011). Currently, non-formal and informal learning as part of lifelong learning are acknowledged as crucial for the constant development of professionals to cope with the ever-growing challenges of the world of work. However, it is essential that these learning forms be transformative in line with Laal's (2011) definition of learning so that they can produce high quality professional learning involving perspective changes from passive views to conceptualized, active views (Stewart, 2014).

\section{Transformative Learning}

Transformative learning distinguishes between learners as recipients of knowledge versus learners who are actively engaged through critical reflection and discourse to question assumptions, expectations, and context to achieve deeper meaning and new perspectives to guide their actions (Laal, 2011). It is considered a complex way of learning and is a "theory in progress and a subset of adult learning" (Cranton, 2006 in Santalucia \& Johnson, 2010, p. 1).

Transformation embraces the idea that learning goes beyond quantifiable and recognizable territories questioning our understanding of the world or "frame of reference" when there is a challenge to our belief systems (Cranton \& King, 2003).

Many situations in education provide teachers with the opportunity for transformative learning on a daily basis while teaching. However, the presence of these situations is meaningless if transformative learning is not nurtured. How transformative learning is fostered within formal education varies considerably 
and depends on one's theoretical perspective (Dirkx, 1998), and whether it's carried out by formal, non-formal, or informal methods. For transformative teacher learning to happen, it is necessary for the presence of a structured means of self-reflection that possesses elements of formal and informal learning such as content or description of problems to be analyzed, problem-solving strategies, and premise of reflection (Mezirow, 1991). Transformative learning as a theory was introduced by Mezirow who, after conducting empirical research, concluded that "we make meaning of the world based on our own experiences" (Stewart, 2014, p. 32). Transformative learning and its relationship with informal learning is especially important since nowadays there is a tendency of equating formal standardized professional development courses with actual professional learning, which can cause several downsides, indeed, the transfer of knowledge acquired on formal training can be significantly low if the training is not performed efficiently (Nafukho et al, 2017).

\section{Historical Context of Transformative Learning}

The theories of learning in the first half of the $20^{\text {th }}$ century originated from attempts to create psychological theories explaining the learning process (Schunk, 2012). These theories were then expanded to create a structural framework in response to the educational needs of post-industrial nations.

However, during the latter half of the $20^{\text {th }}$ century, large-scale social movements changed the fabric and identity of modern society. Among these was the rapid growth of the participation rates of women in the workforce. Within the United States, the economy expanded in the decades after World War II and this growth brought with it an increased demand for labor (Toossi, 2002). The women's rights movements and accompanying legislation increased equal opportunities in the workplace and was conducive to creating a climate that enabled more women to work. During the 1970 s-80s, $24 \%$ of the US labor force growth was due to an increase in participation rates by women in the workplace (Toossi, 2002). In addition, the United States was also experiencing the civil right movement and the increasing integration of various ethnic minorities_predominantly African-American and Hispanic_- within the workforce and places of higher education.

Professional or academic achievements for women and minorities were not part of the dominant, popular 'success' paradigm held at the time. Though the paradigm was already being questioned in the 1970s, it had not been challenged to the extent that it is today in developed nations. Thus, if behaviorist theories 
of learning were applied to such learners, their ingrained habits from a previous lifetime of socio-cultural conditioning would, in fact be, the largest obstacles to any further advancement in their accrual of professional or academic knowledge, or ideation of advancement in professional or academic life (Engeström \& Sannino, 2012).

Behaviorist learning failed to explain how or why these women broke free from ingrained habits of mind to think in a manner that was still considered radically different from the norm. The established behaviorist pedagogical models of teaching also failed adult learners in general:

"One problem was that pedagogy was premised on a conception of the purpose of education-namely, the transmittal of knowledge and skills that had stood the test of time- that adult learners seemed to sense was insufficient. Accordingly, their teachers found them to be resistant frequently to the strategies that pedagogy prescribed, including fact-laden lectures, assigned readings, drills, quizzes, rote memorizing, and examinations. Adults appeared to want something more than this, and drop-out rates were high."

(Knowles, 1980, p. 40)

Social-cognitive theories of learning and teaching would fail such learners within these specific time and place settings. Bandura's ideation of learning (Ponton \& Rhea, 2006) operated within a triadic reciprocal feedback loop between the learner, the knowledge or behavior, and their environment; this feedback loop would collapse in such a setting primarily because this was a time of social and cultural uncertainty. Social-cognitive learning requires the presence of model individuals from whom a learner acquires skills through observation and gains insight into the application of those skills within their appropriate context. However, during this period of socio-cultural upheaval, there was a marked absence of models who had not experienced the same journey of acquisition of knowledge or capability.

Furthermore, many of these learners — as well as many of their teachersexperienced culture shock in the pursuit of academic or professional goals. In this context, culture shock is defined as "primarily a set of emotional reactions to the loss of perceptual reinforcements from one's own culture to new stimuli which have little or no meaning and to the misunderstanding of new and diverse experience" (Adler, 1975, p.13 as cited in Lyon, 2002, p. 3).

Because of these societal changes, new forms of learning and teaching models gained popularity, particularly the notion of Andragogy. Andragogy was popularized by Malcolm Knowles in the 1960s and 1970s, though the basis of 
this theory had been established far earlier in the 1920s through Eduard Lindeman's publication of "The Meaning of Adult Education." Andragogy was defined as "the art and science of helping adults learn", as opposed to pedagogy which was primarily concerned with child development.

This collection of theories had five basic assumptions as dictated by Knowles's andragogical model:

1. Adult learners move from being dependent personalities towards being self-directed and may exhibit dependent learning preferences at first only due to prior schooling experiences as children.

2. Adult learners come to learning activities with a greater volume and quality of experience than children.

3. Learning activities for adult learners are oriented to development tasks and hence are more specific in terms of a specific desired output than children.

4. The initial trigger for adult learners is more problem-centered than subject-centered, and so adult learning have a more urgent timeline for a desired learning outcome than youth.

5. Adult learners are more internally motivated to learn, as opposed to younger learners who are more externally motivated (Knowles, 1980; Baumgartner et al, 2003).

However, although andragogy provided a fresh departure from the traditional pedagogical paradigms, it failed to help adult learners within this specific historic setting in one crucial way-it ignored the cultural, social, and other contextual inputs within which learning takes place. Knowles's model represented the contemporaneous state of an entire field of education, so it is understandable why andragogy did not provide sufficient weight to the nuances of differences in states of cognition due to the socio-cultural experiences of learners. However, socio-cultural context was the main reason for the increase in the number of adult learners and so this lack of context in the model became a critical flaw in the theory of andragogy. Due to this critical flaw, Mezirow picked up the baton, and proposed the transformative learning theory as an alternative theory to the ones existing before it.

\section{Mezirow's Transformative Learning Theory}

Transformative learning theory was first coined as a term during the 1970s in Jack Mezirow's study of the learning experiences of women returning to post-secondary education or professional workplaces after an extended time away. Mezirow 
utilized qualitative analytical methods to "identify factors that characteristically impede or facilitate" the learning experience of women in their re-entry into the professional or academic world (Mezirow, 1978, as cited in Kitchenham, 2008, p. 105).

Based on their data and subsequent analytical findings, Mezirow and his team deduced that the sample participants had undergone a "personal transformation" and offered a list of 10 phases which the participants had experienced through this period of change.

Kitchenham (2008, p. 105) cites the phases as follows:

Phase 1: A disorienting dilemma;

Phase 2: A self-examination with feelings of guilt or shame;

Phase 3: A critical assessment of epistemic, sociocultural, or psychic assumptions;

Phase 4: Recognition that one's discontent and the process of transformation are shared and that others have negotiated a similar change;

Phase 5: Exploration of options for new roles, relationships, and actions;

Phase 6: Planning a course of action;

Phase 7: Acquisition of knowledge and skills for implementing one's plans;

Phase 8: Provisional trying of new roles;

Phase 9: Building of competence and self-confidence in new roles and relationships;

Phase 10: A reintegration into one's life on the basis of conditions dictated by one's perspective.

Mezirow held 'learning' to be a "process of using a prior interpretation to construe a new or revised interpretation of the meaning of one's experience in order to guide future action" (1996, as cited in Taylor, 1998, p. 5). The basis of Mezirow's 'transformative learning' lies in the idea of a perspective transformation or a change in a learner's worldview. As opposed to informational learningwhich changes "what we know"-transformational learning instead acts upon how we think about the knowledge or experiences with which we come into contact, or "how we know" (Kegan, 2000, as cited in Baumgartner et al, 2003, p. 23). By 2006, over a dozen books, hundreds of academic papers, and over 150 doctoral dissertations had discussed the theoretical and practical implications of transformative learning as an adult learning theory (Mezirow, 2006, as cited in Kitchenham, 2008, p. 120). 


\section{Influencers of Mezirow's Transformative Learning Theory}

The origins of Mezirow's understanding of the transformative process was a result of determining specific experiences that learners encounter during their efforts to re-acclimatize themselves within professional and academic environments after a long hiatus. There are several major influences on Mezirow's early work, including Kuhn's informative work to enable Mezirow's conception of transformative learning, and, most importantly, Freire's and Habermas's influence on the transformative process.

Paulo Freire compared the traditional pedagogies of the dominant educational processes to the "banking" method of learning — wherein a teacher would "deposit" stores of information to those students whom the teacher favored. Within the realm of learning theories, this "banking" method falls under the umbrella of behaviorist theories wherein a set input of knowledge by a teacher would be expected to result in an equivalent and predictable output of learning and capability in a student.

Within this "banking" method of learning, Freire identified the biggest problem as the lack of critical consciousness which such teaching develops within students. Just passively storing information imparted from a teacher to a learner prevents the learner from actively intervening and interacting with the subject material. This lack of involvement leads to a lack of free thought, and increases dependence of the learner on the teacher. To counteract this growing dependence engendered within students, Freire pushed the need to develop a consciousness that has the power to transform reality through the concept of 'conscientization'. Freire defined 'conscientization' as "learning to perceive social, political, and economic contradictions_-developing a critical awareness - so that individuals can take action against the oppressive elements of reality" (Freire, 1970, as cited in Kitchenham, 2008, p. 107).

Critical awareness (Freire, 1970) proposes that a more democratic structure is necessary in formalized education. Rather than a top-down approach where the teacher is the only source of information and knowledge, learning best occurs in a multi-directional one where teachers welcome the input from their students. This practice nurtures transformative relationships between both teacher and student as well as students and society at large. Freire's belief emphasized the idea that education does not end on graduation day but continues in all subsequent parts of life. Therefore, Freire provided Mezirow with a fundamentally important concept of better understanding adult learning. 
Habermas's work provided him with a structure to differentiate between the different types of learning, as understood and accepted within Mezirow's understanding of the learning paradigm:

"Habermas (1984) has helped us understand that there are two major domains of learning with different purposes, logics of inquiry, criteria of rationality, and modes of validating beliefs. One is instrumental learning - learning to control and manipulate the environment or other people, as in task-oriented problem solving to improve performance. The other is communicative learning - learning what others mean when they communicate with you. This often involves feelings, intentions, values, and moral issues" (Mezirow, 2000, p. 8).

For Mezirow, most learning processes involved elements from both these domains, rather than exclusively residing in one domain or the other domain. Habermas also identified a third domain-emancipatory learning - that is more introspective in nature since the learner needs to be self-reflective in order to experience and undergo self-knowledge. In Kitchenham's words, "teachers who consider their beliefs on technology infusion within their social systems of learning and schools and come to an understanding of what, when, and why to infuse would be encountering emancipatory learning" (2008, p. 109).

However, Mezirow did not consider emancipatory learning as a third exclusive domain of learning. Instead, in his theory of transformative learning, he redefined emancipation as a central process which would occur in and pertain to both instrumental as well as communicative learning domains (Hodge, 2007). As such, with advancements in his theory, Mezirow came to view the process of perspective transformation as:

"The emancipatory process of becoming critically aware of how and why the structure of psycho-cultural assumptions has come to constrain the way we see ourselves and our relationships, reconstituting this structure to permit a more inclusive and discriminating integration of experience and acting upon these new understandings" (Mezirow, 1981, as cited in LIOU, 2015).

With further refinements to his theory, Mezirow's transformative learning shows that when 'meaning schemes' and/or overarching 'meaning perspectives' are identified, challenged, and altered, perspective transformations take place, leading to transformative learning. 


\section{Components of Mezirow's Transformative Learning Theory}

According to Mezirow's postulation of transformative learning, perspective transformation occurs when adult learners undergo the process of revising their 'meaning structures'. These 'meaning structures' are essentially culturally-defined frames of reference which are composed of 'meaning schemes' and 'meaning perspectives' (Taylor, 1998). The first component, meaning schemes, are the smaller component among the two, and are "made up of specific knowledge, beliefs, value judgments, and feelings that constitute interpretations of experience" (Mezirow, 1991, as cited in Taylor, 1998, p. 38). These meaning schemes represent the more easily definable behaviors, habits, and expectations which individuals outwardly display on a regular basis, and are the more tangible constituents of meaning structures. Challenges to and changes in meaning schemes are a frequent occurrence in the lives of any functional, thinking, learning adult.

However, if meaning schemes make up the minutiae of what constitutes human behavior, then 'meaning perspective' is a learner's frame of reference as stated by Mezirow:

"It is the structure of assumptions and expectations through which we filter sense impressions. It involves cognitive, affective, and conative dimensions. It selectively shapes and delimits perception, cognition, feelings, and disposition by predisposing our intentions, expectations, and purposes. It provides the context for making meaning within which we choose what and how a sensory experience is to be construed and/or appropriated" (Mezirow, 2000, p. 16).

According to Mezirow, our frames of reference are based on cultural paradigms and personal perspectives, and are supplemented by intentionally or incidentally learned philosophical, economic, sociological, and psychological orientations (Mezirow, 2000). Cultural paradigms often represent collectively held frames of reference which are assimilated from the culture of a learner, while personal perspectives are mainly derived from the idiosyncrasies of primary caregivers. To Mezirow, a frame of mind is composed of a habit of mind and its resulting points of view. The latter-a habit of mind-is made up of a set of broad and generalized assumptions and predispositions in the mind of a learner through which they interpret the meaning of any experience. Mezirow provides the following examples:

1. Sociolinguistic (cultural canon, ideologies, social norms, customs, "language games", secondary socialization)

2. Moral-ethical (conscience, moral norms) 
3. Epistemic (learning styles, sensory preferences, focus on the whole or parts, or on the concrete or abstract)

4. Philosophical (religious doctrine, philosophy, transcendental worldview)

5. Psychological (self-concept, personality traits or types, repressed parental prohibitions that continue to dictate ways of feeling and acting in adulthood, emotional response patterns, images, fantasies, dreams)

6. Aesthetic (values, tastes, attitudes, standards, and judgments about beauty and the insight and authenticity of aesthetic expressions, such as the sublime, the ugly, the tragic, the humorous, the "drab", and others) (Mezirow, 2000, p. 17)

These habits of mind constitute the core of a learner's self-identification and cognitive reasoning. For example, habits of mind impact whether a person considers themselves a liberal or conservative, whether they approach problems analytically or intuitively, whether they prefer to work with others or alone, whether they have a favorable view of people with experiences and backgrounds different from their own, and other intentionally or accidentally learned underpinnings of a learner's self-consciousness which inform their worldview.

It is these habits of mind that then outwardly become expressed as points of view. A point of view is composed of complementary clusters of meaning schemes that affect how individuals view cause-effect relationships. Thus, they usually tend to suggest a line of action to any learner which an individual tends to follow automatically, unless these basic presuppositions are brought into critical reflection (Mezirow, 2000, p. 18). However, most learners hold perspectives which are highly individualized and isolated, giving rise to a worldview that reflects their own subjective version of reality rather than an empirical reality.

In Mezirow's transformative learning, the process of learning occurs in one of four ways - by expanding upon our existing frames of reference, by learning new frames of reference, by transforming points of view, or by transforming habits of mind (Mezirow, 2000). A learner must question their own assumptions and the context within which they were formed, and critically reflect upon ingrained beliefs, in order to question their own evaluation of cause and effect relationships.

To explain this self-assessment, Mezirow utilizes Brookfield's breakdown of the three most common assumptions for critical reflection:

1. Paradigmatic assumptions that structure the world into fundamental categories (the most difficult to identify in oneself); 
2. Prescriptive assumptions about what we think ought to be happening in a specific situation;

3. Causal assumptions about how the world works and how it may be changed (the easiest to identify) (as cited in Mezirow, 2000, p. 19).

According to Mezirow, transformative learning cannot fully occur when a learner isolates their meaning perspective and resists outside input or any contradicting experience to challenge their pre-existing habits of mind. The process of transformative learning requires that a learner move from a more subjective frame of reference, based on their own past beliefs and habits, to "a more fully developed (more functional) frame of reference... one that is more (a) inclusive, (b) differentiating, (c) permeable, (d) critically reflective, and (e) integrative of experience" (Mezirow, 1996, as cited in Taylor, 1998, p. 14).

Overall, the experience of transformative learning is a worldview shift, a change in the meaning perspective through which a learner identifies themselves and develops habits of mind through which they interact with the world around them. When a learner engages with a new experience, either intentionally or accidentally, it is assessed through the lens of their existing meaning perspective. Depending on the degree of congruency of this new experience with their existing meaning perspective and the presuppositions which form its anchors, this experience either reinforces their existing beliefs or challenges them. If the experience is congruent with the current perspectives of a learner, but isn't entirely complementary to all their fundamental underpinnings, it may stretch the boundaries of their worldview without truly transforming it.

However, transformative learning takes place when a learner interacts with experience or knowledge that is truly and deeply incongruous with their meaning perspective. Such an experience can't be assimilated into their current worldview, since it conflicts with their philosophical, moral, social, or any such other fundamental beliefs that constitute their meaning perspective. In such a case, the experience may either be rejected, or the meaning perspective is transformed to accommodate and assimilate this new information. This experience then gives rise to a new meaning structure, which then interacts with existing meaning schemes in ways hitherto not experienced by the learner, thus giving rise to new knowledge of the self and the world around the learner. In essence, a transformation takes place. This transformation may be "epochal, a sudden, dramatic, reorienting insight, or incremental, involving a progressive series of transformations in related points of view that culminate in a transformation in habit of mind" (Mezirow, 2000, p. 21). 
Main Themes of Mezirow's Transformative Learning Theory

The first theme in Mezirow's theory is experience, and the totality of a past learner's experience and their accumulated knowledge, whether formal or informal, intentional or accidental, plays a key central role in the process of transformative learning (Rose, Loewenthal \& Greenwood, 2005). Mezirow (2018) considers the process of transformation as a shift from "a prior interpretation to construe a new or revised interpretation of the meaning of one's experience" (p. 116). This store of experience within a learner is also the foundation which informs their current meaning perspective, the base from which habits of the mind are created, and the lens through which learners perceive, interpret, and make meaning of their world (Mezirow 1991, as cited in Taylor \& Cranton, 2013, p. 35). To Mezirow, experience "constitutes a starting point for discourse leading to critical examination of normative assumptions underpinning the learner's... value judgments or normative expectations" (Mezirow, 2018, p. 114).

This prior experience becomes the raw material of a transformative learning process. Mezirow's ideation of 'experience' as the raw material does not limit itself to stores of knowledge and interactions accumulated through a formal learning mechanism. It is, in fact, the interaction between meaning schemes accrued through formal learning, meaning schemes accrued through personal knowledge from informal learning, as well as the cultural perspective through which a learner develops their meaning perspective that collectively formulates the learner's worldview.

Within the complex process of transformative learning and the abundance of feedback loops, the overarching theme that governs the process is critical reflection. Mezirow uses the term 'critical reflection' as a means of specifically addressing the base presuppositions upon which a problem is built and the way in which variables are defined. Mezirow also described this sub-process of transformative learning as 'premise reflection' (Mezirow, 1990). In the wake of a new experience or store of knowledge, which may be incongruous with a learner's previously held experience and worldview, it is critical reflection that allows them to discover a new lens of perspective-taking for assimilation of that information. Through this process, learners can embark upon a progressive series of minor transformations that lead to an experience of transformative learning or through discovering a never-before experienced worldview.

The final overarching theme which governs the process of transformative learning is reflective discourse. In the context of transformative learning, discourse is "that specialized use of dialogue devoted to searching for a common understanding and assessment of the justification of an interpretation or belief" 
(Mezirow, 2000, p. 10). Critical reflection allows an individual learner to question those biases and presuppositions which form the foundation of their perspective and to move towards a more functional worldview. However, to engage in critical reflection without considering the perspectives of others can result in a meaning structure that is subjective and constrained.

Reflective discourse allows the learner to determine the truth of their perspectives (Baumgartner et al, 2003). While critical reflection directs a learner down a path of self-questioning, reflective discourse allows the learner to tap into a pool of collective experiences to be effective in their decision-making (Mezirow, 2000). Reflective discourse allows a learner to move from their own isolated view of reality to a comparative objective perspective of the phenomena. This requires a consensus building process in discussing common and differing points of one's worldview with other learners, through the application of an awareness of one's own presuppositions, empathy towards others during the discourse, and self-control to maintain one's integrity.

\section{Review of Mezirow's Theory}

There has been some critique of Mezirow's transformative learning theory in that several academics believe the theory fails to analyze the importance of gender and the historical origins of the theory (Baumgartner et al, 2003), and that it fails to provide sufficient weight to racial group identity while focusing too much attention on the individual (Caruth, 2001; Baumgartner et al, 2003). However, these criticisms are not entirely justified.

Mezirow provided a window of insight into how an adult learner's mind works when they step outside their comfort zone. This is similar to Vygotsky's zone of proximal development, which is the difference between what a learner can do without help and what they are unable to do (Yasnitsky, 2018). Based on transformative learning theory, previous experiences fail to inform the learner of possible next steps to resolve obstacles leading to a culture shock. For example, a novice professional with a background in marketing and sales switches to the field of HR. The prior professional experience of the novice professional is unhelpful, or their dawning view of their deficiencies is significantly less jarring than that of a life-long housewife who has acquired the same HR job. Based on transformational learning theory, both novice professionals experience a sense of shock and discomfort in their current position, lack the skill-set or knowledge necessitated by their displacement into an unfamiliar role, and both need to reenvision themselves to acclimatize and initiate their knowledge-building efforts. 
Although the exact nature of their internal struggle depends on the individual's unique meaning perspective, the journey remains comparable in terms of the steps undertaken.

Based on socio-cultural identity, socio-economic background, professional knowledge and skill-set, or ethnic background, there will always be elements of an adult's experience and meaning perspective which translate to new circumstances when changes occur. In today's society when "transferability (as a cognitive acquisition principle) and mobility (in the European labor market...)" (Nijhof \& Nieuwenhuis, 2008, p. 4) are high on the current professional agenda, jarring changes at points in an adult learner's life are inevitable.

Both the unique needs of adult learners, as well as the necessity for European professionals to learn in increasingly cross-cultural environments are fulfilled within the tenets of Mezirow's theory. In fact, Lyon (2002, p. 4) states that the core concepts of initiation of transformative learning are fundamental concepts in the study of cross-cultural adaptability and adjustment to new host cultureswhether social, economic, political, or geographical.

In response to other critics such as Naughton $\&$ Schied (2010), this paper argues that this logic is well-grounded. However, the inherent goodness of the transformative experience in this type of learning is not a judgment of moral concepts but on whether the experience can deliver a tool in response to a need. Today, professionals need to adapt to frequent change and it is society's responsibility to provide such tools for effective change. In its ability to deliver these requisite tools for change, the transformative experience can be an effective process. As such, Mezirow's transformative learning theory is an educational path which is uniquely well-suited to the current European marketplace's needs and is aligned with the European Union's goal to become a knowledge-driven society.

\section{Applications of the Transformative Learning Theory in Formal and Informal Learning}

Based on the transformative learning framework, there are several recommendations for practical applications by applying critical reflective thought to Cranton's and King's domains - content, premise, and strategy (Wang \& King, 2008). These recommendations are applicable within the context of andragogy rather than pedagogy. Teachers who are responsible for adult and higher education programs have more flexibility with additional lesson planning in most European countries than their counterparts who engage with younger student-learners in 
school. Moreover, there is a current need to adequately equip professional learners with skills so a focus on this type of learner takes priority. Since adult learners have more prior experiences and are better equipped to differentiate between relevant and irrelevant knowledge, they are more likely to benefit from transformative learning tools.

Today's professionals are experiencing a divide between current knowledge and what they are expected to know for successful job performance; however, there is a lack of understanding between the curricula and the realities within a profession. Today's training professionals are limited in their ability to create courses to satisfy the needs of all learners to prepare for corporate life. Most companies have different ways of structuring their organizations and have unique internal processes and procedures, based on the size of the organization. Outside of courses for science-related fields, wherein methodology, principles, and procedures rarely vary, it becomes difficult to ascertain what a learner needs to learn.

However, it is possible to supplement standardized courses to give a student-learner more agency in what they need to learn. To do this, teachers should implement apprenticeships at the beginning of a study course, in addition to projects and internships that occur towards the end of a course. These apprenticeships need not occur in large-scale companies, but should ideally occur in the fields that the students have chosen for their study. Short apprenticeships at the start of a course-monitored regularly by the teacher-enable a student-learner to critically gauge any standardized content and identify weaknesses within their own skill-sets which can then be learned through their academic development pathway. This enables students to link theoretical knowledge and practical experience. Internships are often used to introduce students to their post-academic professional experience while still having the advantage of a teacher-learner relationship from which to draw support.

In using the transformational learning paradigm, once a learner starts interacting with standardized content, this process enables them to question their own shortcomings, and allows a teacher to start nurturing the tools required for a lifetime of transformative learning with the initial apprenticeship providing the trigger event. By establishing this experience as a foundational marker at the beginning of their higher education experience, teachers provide students with a 'desire to change' or the motivation to go through a transformative learning process (Taylor \& Cranton, 2013). Lytle’s study provides good insight into the vital role played by this transformative learning process. The study analyzed the experiences of 20 registered nurses when they returned to school to obtain a bachelor's degree in nursing, and examined how closely the nurses followed 
the 10-step process of transformative learning. While 7 nurses completed all ten steps, thirteen others stalled at different points in the process (Lytle, 1989, as cited in Baumgartner et al, 2003). The study shows the importance of individual trajectories through the transformative learning process.

To allow transformative learning to take place, learners must have autonomy in order to question their own assumptions on how they learn and how they process what they learn. Teachers can help student-learners become more aware of their psychological-cognitive types, since each unique type has their own response and preferred way of learning when it comes to activities (Taylor $\&$ Cranton, 2003). As such, Cranton states that "case studies, debates, critical questioning, and analyses of theoretical perspectives" promote the process of transformative learning in "thinking" type of learners who enjoy logic as their primary tool. Intuitive types profit more from brainstorming activities, while experiential learners prefer simulations. Non-confrontational student-learners profit from being placed together in "harmonious groups" to ideate over alternative viewpoints rather than engage in confrontational activities like debates (Cranton \& King, 2003).

However, in moving from critically reflecting upon strategies to allowing for reflection, the role of the teacher becomes more important. Carl Rogers provides a transformative andragogical experience through the person-centered group process and this allows learners to question and critically reflect upon their own premises, while also providing a stage for reflective discourse (O'Hara, 2004). This stage depends the most upon the formal and informal experiential knowledge of the teacher to translate the process into successful experiential exercises. One example of this is through group exercise, whereby the teacher forms groups composed of student-learners with different perspectives to ensure debate occurs, while ensuring that learners voice their opinions free of judgment and recrimination. The purpose of these types of groups is to open a non-competitive discourse wherein all participants move towards a shared middle ground of their different perspectives.

Lastly, upon completion of courses, teachers can engage with their graduate students after a period of three or six months' post-professional engagement. At this point, the most important line of discussion with recent graduates focuses on the following questions:

1. What would you have liked to learn differently?

2. What additional information would you have liked to learn?

In asking these questions, it is expected that the teacher encourages them to reflect upon their past experiences, as viewed through their current lenses as 
working professionals. It is expected that this process yields significant responses in terms of suggestions for inclusions or changes in standardized curricula.

While more research needs to be done to test the application of transformative learning theory in the real world, this approach to teaching and learning is a fruitful pathway to understand the formal and informal knowledge and experience of both teachers and learners in the educational process. In addition, transformative learning grants vital tools to learners to ease the burden of transitioning through the process of acquiring new skill-sets and knowledge for future professionals.

\section{Conclusion}

Transformative learning could be a key part of lifelong learning because it increases knowledge, builds skills, and increases social development through enhanced awareness of the self and environment as well as one's competitiveness and employability. Both formal and informal learning are essential for professional advancement. For formal and informal learning to be effective, they must be based on a learning framework, which is Mezirow's transformative learning theory in this case.

From the historical context of the theory, transformative learning was the key to revolutionizing adult learning, liberated women from gender-based setbacks and led to Mezirow's transformative theory. Furthermore, an analytical review of Mezirow's theory has shown that the theory gives lifelong learning meaning structures, frames of reference, and habits of mind necessary for active, conceptualized learning when a learner has an experience that is incongruous with their meaning perspective. Similarly, through the theory's themes of experience, critical reflection and reflective discourse, learners build a foundation for new knowledge, discover a new lens of perspective, and evaluate the truth of these perspectives.

The world we live in is a knowledge-based society. Teachers at the starting point of the ever-changing cycle of learning, must be opened to learning and acquiring new knowledge created within the institutions, networks and organization in order to maintain competence at their roles and duties. In the same way, organizations at the academic, corporative and non-corporative level must be prepared to facilitate the learning processes and foster the development of transformative learning in their members in order to fulfill personal, professional and corporate needs through high-quality lifelong learning. 


\section{References:}

Baumgartner, L. M., Lee, M. Y., Birden, S., \& Flowers, D. (2003). Adult Learning Theory: A Primer. Information Series.

Bernstein, B. (1971). Class, codes and control. Volume 1: Theoretical studies towards a sociology of language. London and Boston: Routledge and Kegan Paul.

Billet, S. (2002). Toward a workplace pedagogy: Guidance, participation and engagement. Journal of Adult Education 53(1), 27-43.

Billett, S. (2004). Workplace participatory practices: Conceptualising workplaces as learning environments. Journal of workplace learning, 16(6), 312-324.

Caruth, D. D. (2001). African American male transformative learning: An Afrocentric study of the Million-Man March (doctoral disertation). University of Wyoming.

Cheetham G., \& Chivers G. (2001). How professionals learn in practice: An investigation of informal learning amongst people working in professions. Journal of European Industrial Training, 25, 247-292.

Colley, H., Hodkinson, P. And Malcolm, J. (2003). Informality and formality in learning: A report for the learning and skills research centre. London: Learning and Skills Research Centre.

Collins, A., \& Halverson, R. (2010). The second educational revolution: Rethinking education in the age of technology. Journal of Computer Assisted Learning, 26(1), $18-27$.

Communication from fhe Commission. (2006). Adult learning: It is never too late to learn. Communication from the commission. European Commission, Brussels.

Cranton, P., \& King, K. P. (2003). Transformative learning as a professional development goal. New directions for adult and continuing education, 98, 31-38.

Department of Education and Science. (2000). Learning for Life: Paper on Adult Education. Dublin: Stationery Office. Retrieved from http://eric.ed.gov/PDFS/ ED471201.pdf

Dirkx, J. M. (1998). Transformative learning theory in the practice of adult education: An overview. PAACE journal of lifelong learning, 7, 1-14.

Du Plessis, A. J. (2009). An overview of the influence of globalisation and internationalisation on domestic Human Resource Management in New Zealand. International Review of Business Research Papers, 5(2), 1-18.

Engeström, Y., \& SAnnino, A. (2012). Whatever happened to process theories of learning?. Learning, Culture and Social Interaction, 1(1), 45-56.

Eraut, M. (2004). Informal learning in the workplace. Studies in Continuing Education, 26(2), 247-273.

Freire, P. (1970). Pedagogy of the oppressed (MB Ramos, Trans.). New York: Continuum, 2007.

Hodge, S. (2007). The transformative potential of adult literacy learning. In Adult Learning and Literacy: Policy and Practice (pp. 1-20). Adult Learning Australia.

ILLERIS, K. (2004). Transformative learning in the perspective of a comprehensive learning theory. Journal of Transformative education, 2(2), 79-89. 
Kitchenham, A. (2008). The evolution of John Mezirow's transformative learning theory. Journal of transformative education, 6(2), 104-123.

Knowles, M. S. (1980). The modern practice of adult education: From pedagogy to andragogy. Englewood Cliffs, NJ: Cambridge Adult Education.

Laal, M. (2011). Lifelong learning: What does it mean?. Procedia-Social and Behavioral Sciences, 28, 470-474.

Liou, C. P. (2015). Discovering new selves: college students' perceptions of their perspective transformation through service-learning. Paper presented at the 5 th AsiaPacific Regional Conference on Service-Learning: Love Journey: Community Engagement through Service-Learning, Fu Jen Catholic University, Taiwan.

Lyon, C. R. (2002). Trigger event meets culture shock: Linking the literature of transformative learning theory and cross-cultural adaptation (ED472072). Raleigh: North Carolina State University.

Malcolm, J., Hodkinson, P., \& Colley, H. (2003). The interrelationships between informal and formal learning. Journal of workplace learning, 15(7/8), 313-318.

Mezirow, J. (1990). How critical reflection triggers transformative learning. Fostering critical reflection in adulthood, 1(20), 1-6.

Mezirow, J. (1991). Transformative dimensions of adult learning. San Francisco: JosseyBass.

Mezirow, J. (2000). Learning as transformation: Critical perspectives on a theory in progress. Jossey-Bass.

Mezirow, J. (2018). Transformative learning theory. In K. Illeris (Ed.,) Contemporary Theories of Learning Theorists ... In Their Own Words (pp. 114-128). Routledge.

Nafukho, F. M., Alfred, M., Chakraborty, M., Johnson, M., \& Cherrstrom, C. A. (2017). Predicting workplace transfer of learning: A study of adult learners enrolled in a continuing professional education training program. European Journal of training and Development, 41(4), 327-353.

Naughton, D., \& Schied, F. (2010). Disturbing outcomes: The dark side of transformative learning.

Nijhof, W. J., \& Nieuwenhuis, L. F. (2008). The learning potential of the workplace. In W. J. Nijhof \& L. F. Nieuwenhuis (Eds.), The Learning Potential of the Workplace (pp. 3-13). Rotterdam: SENSE publishers.

Ohara, M. (2004). Maximizing e-learning ROI: Identifying successful online learners. In Allied Academies International Conference. Academy of Organizational Culture, Communications and Conflict. Proceedings (Vol. 9, No. 1, p. 49). Jordan Whitney Enterprises, Inc.

Ponton, M. K., \& RheA, N. E. (2006). Autonomous learning from a social cognitive perspective. New Horizons in Adult Education and Human Resource Development, 20(2), 38-49.

Santalucia, S., \& Johnson, C. R. (2010). Transformative learning: Facilitating growth and change through fieldwork. OT Practice, 15(19), CE1-CE7.

Schunk, D. H. (2012). Learning theories an educational perspective sixth edition. Pearson. 
Scribner, S., \& Cole, M. (1973). Cognitive Consequences of Formal and Informal Education: New accommodations are needed between school-based learning and learning experiences of everyday life. Science, 182(4112), 553-559.

Stewart, C. (2014). Transforming professional development to professional learning. Journal of Adult Education, 43(1), 28-33.

TAYLOR, E. W. (1998). The Theory and Practice of Transformative Learning: A Critical Review. Information Series No. 374.

Taylor, E. W., \& Cranton, P. (2013). A theory in progress? Issues in transformative learning theory. European journal for research on the education and learning of adults, 4(1), 35-47.

Tissot, P., \& Centre européen pour le déVeloppement de la formation profesSIONNELLE. (2004). Terminology of vocational training policy: a multilingual glossary for an enlarged Europe. Luxembourg: Office for official publications of the European Communities.

Toossi, M. (2002). A century of change: The US labor force, 1950-2050. Monthly Lab. Rev., 125, 15.

WANG, V. C., \& KING, K. P. (2008). Transformative learning and ancient Asian educational perspectives. Journal of Transformative Education, 6(2), 136-150.

YAng, J., \& VAldÉs-Cotera, R. (2011). Conceptual Evolution and Policy Developments in Lifelong Learning. UNESCO Institute for Lifelong Learning, Hamburg, Germany.

Yasnitsky, A. (2018). Vygotsky: An Intellectual Biography. London and New York: Routledge 
Deisi C. Yunga ${ }^{3}$

Univerzitet „Etveš Lorand“, Mađarska

\section{Transformativno učenje: bogatstvo formalnosti i neformalnosti ${ }^{4}$}

Apstrakt: Ideja učenja po završetku formalnog obrazovanja svojevremeno nije predstavljala suštinski element profesionalnog razvoja. Danas se neformalno i informalno učenje u okviru celoživotnog sticanja znanja i razvoja smatra ključnim elementom kontinuiranog napretka profesionalaca, koji im je neophodan za obračunavanje sa rastućim izazovima u sferi rada. U ovom radu je primenjena metodologija eksplorativnog istraživanja da bi se ispitalo kako celoživotno učenje kao metodologija i strategija profesionalnog razvoja može da se uspostavi putem formalnog i neformalnog učenja koje se zasniva na teoriji transformativnog učenja i oslanja na njene smernice. Relevantnost, efikasnost i primenljivost metodologije transformativnog učenja za profesiju nastavnika se procenjuju razmatranjem istorijskog konteksta, tema, elemenata i kritičkom analizom Mezirovljeve teorije transformativnog učenja.

Ključne reči: transformativno učenje, formalno učenje, neformalno učenje, celoživotno učenje, teorija transformativnog učenja

\footnotetext{
${ }^{3}$ Deisi C. Yunga, program EDiTE, Institut za obrazovanje odraslih Univerziteta „Etveš Lorand“ u Budimpešti, Mađarska (deisi.yunga@gmail.com).

${ }^{4}$ Ovaj rad je napisan u sklopu projekta pod finansijskim pokroviteljstvom programa istraživanja i inovacija „Horizon 2020“ Evropske unije, u okviru ugovora o stipendiji Marija Sklodovska-Kiri broj 676452.
} 